\title{
Past, Present, and Future in the Relationship between Growth Retardation and the IGF System: Excerpts from the Cesar Bergada Lecture Given during the SLEP 2015 Annual Meeting
}

\author{
Héctor Jasper \\ Centro de Investigaciones Endocrinológicas "Dr. César Bergadá" (CEDIE), Buenos Aires, Argentina
}

\author{
Keywords \\ Growth retardation · Insulin-like growth factors · Idiopathic \\ short stature $\cdot$ IGF-binding proteins
}

\begin{abstract}
This mini review presents a personal view about the past, the present and the future of the relationship between growth retardation and the IGF system. Looking back, it is pertinent to include a brief look at the evolution of the somatomedin hypothesis, the use of IGF-I determinations in the clinic, and a review of the literature beginning in the late 1980 s with the description of mutations in the Growth Hormone Receptor (GHR) gene. The present possibly started in the mid-1990s with the description of mutations in the IGFI gene, followed in 2003 by reports of mutations in the genes coding for the IGF-I receptor and in the signal transducer and activator of transcription 5b (STAT5b). Finally, in 2004, mutations in the IGFALS gene were described. A diffuse limit between the present and the future might have been reached (the author's arbitrary decision) with the clinical applications of whole exome sequencing, which rapidly showed mutations in genes coding for STAT3, PAPP-A2 (pregnancy-associated plasma protein A2), and IGF-II.
\end{abstract}

(c) 2016 S. Karger AG, Basel

\section{KARGER}

๑) 2016 S. Karger AG, Basel

E-Mail karger@karger.com

www.karger.com/hrp
Growth hormone (GH) acts on growth primarily by regulating the expression of IGF-I in both hepatic and nonhepatic tissues. In nonhepatic tissues, aside from GH, other growth factors and cytokines act upon local growth by mechanisms either dependent or independent of IGFI expression.

The binding of $\mathrm{GH}$ to the cell surface homodimeric GH receptor (GHR, a cytokine superfamily receptor) stimulates four different intracellular signaling pathways affecting: (a) inhibition, (b) transcription, (c) proliferation, and (d) metabolism [1] (Fig. 1). The established components of the IGF system include IGFs (IGF-I and IGF-II), type I and type II IGF receptors, IGF-binding proteins (IGFBPs), and IGFBP proteases (Fig. 2).

\section{The Past}

The IGF field started in 1957, with a paper by Salmon and Daughaday [2]. They reported 3 sets of experiments. First, the incubation of rat cartilage from normal, hypophysectomized (hypox), and hypox rats injected with $\mathrm{GH}$, evaluating the incorporation of radioactive sulfate by cartilage in vitro. They found that incorporation was reduced by hypophysectomy, and could be restored by GH 
administered in vivo. The second experiment involved incubation of rat cartilage from hypox rats with buffer or normal rat plasma. They concluded that plasma from normal rats contains a factor, termed sulfation factor, which promotes sulfate uptake in vitro by cartilage from hypox rats. The last experiment involved cartilages from hypox rats incubated with serum from hypox rats treated with GH. They concluded that the sulfation factor ap-

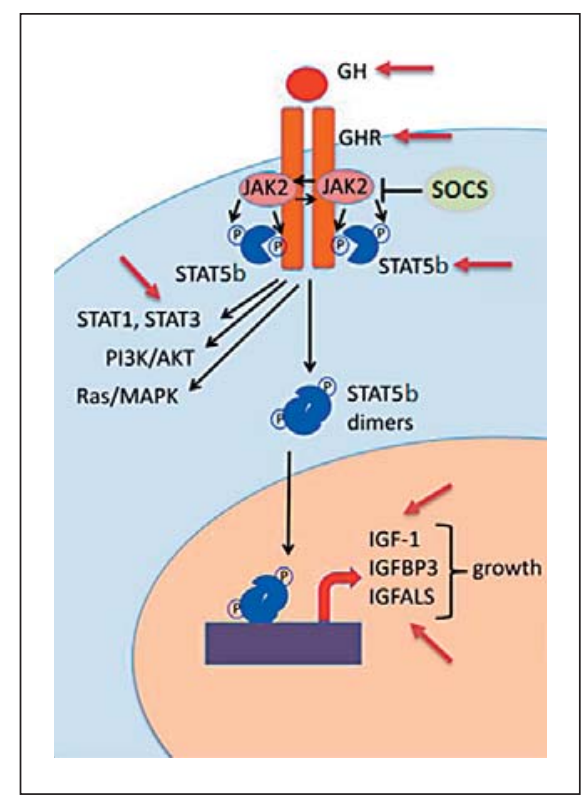

Fig. 1. $\mathrm{GH}$-activated intracellular signaling. Binding of the $\mathrm{GH}$ to its receptor is followed by the activation of several intracellular pathways (inhibitory, metabolic, proliferative, and transcriptional; more details in text). Circled P denotes phosphorylation. Straight arrows indicate reported gene mutations. Modified from Casanova et al. [1]. pears to be GH induced, since it appears in the plasma of hypox rats after the administration of GH. Over time, sulfation factor was named nonsuppressible insulin-like activity, somatomedin, and finally insulin-like growth factors (type I and type II, IGF-I and IGF-II).

By 2001 the somatomedin hypothesis had passed 3 stages [3]:

A An endocrine mechanism in which $\mathrm{GH}$, acting on the liver, stimulated IGF-I synthesis. IGF-I reached cartilage via the circulation, and this induced growth.

B Afterwards, the dual effector hypothesis was postulated. GH had both a direct effect on cartilage growth, and an indirect effect via stimulation of autocrine or paracrine actions of IGF-I at the cartilage level.

C Finally, an expanded theory postulated the existence of both GH-dependent postnatal growth, and GH independent (IGF-I mediated) growth. The GH-dependent part is a combination of the endocrine somatomedin hypothesis with the dual effector hypothesis. The GHindependent part depends on autocrine/paracrine IGF-I, and occurs during embryonic and early postnatal somatic growth, and during cyclic growth of the ovary and uterus.

In 2007, Kaplan and Cohen [4] proposed that the IGFs, rather than effectors of $\mathrm{GH}$ action, are augmentative hormones that amplify the anabolic actions of GH while countering its potentially deleterious effects. Because the IGFs act counter to some but not all the effects of GH, their insulin-like effects may act against GH-stimulated gluconeogenesis and enhanced lipolysis. On the other hand, their anabolic actions are generally augmentative, adding to those of GH through the $\mathrm{GH}$-independent stimulation of protein synthesis and inhibition of proteolysis. These
Fig. 2. Main components of the IGF system. Ligands: IGF-I and IGF-II. High-affinity binding proteins: IGFBP-1 to 6. Lowaffinity IGFBPs fragments. Specific IGFBP proteases. Type I IGF receptor binds IGF-I and IGF-II. Type II IGF receptor binds IGF-II. Specific IGFBPs receptors. Low-affinity IGFBP fragments free IGFs, allowing their binding to receptors.

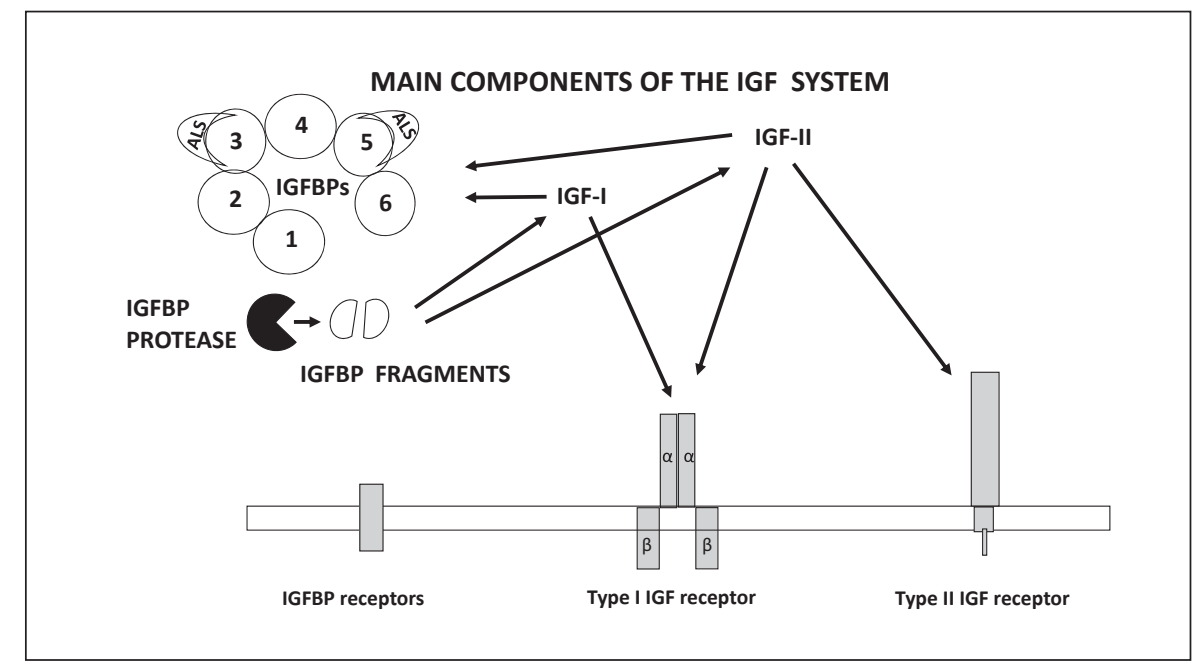


authors think that these actions, considered within the process of evolutionary survival, would benefit the organism by favoring the positive effects of protein anabolism and growth while avoiding the potentially deleterious consequences of hyperglycemia and loss of lipid stores.

At the dawn of our knowledge of the IGF system, studies of serum IGFs used bioassays, like the one employed by our group, using chick embryo pelvic leaflets [5]. In this way, it was possible to show that hypopituitary patients had significantly reduced somatomedin activity, in this case compared with age-matched normal controls (Fig. 3).

In the same 1983 paper, somatomedin activity was evaluated in 16 idiopathic short stature (ISS) patients. Five out of $16(31 \%)$ presented with low somatomedin activity, indicating a possible defect in the IGF system (Fig. 4). In at least 3 different cohorts of ISS children, our group has always found $30-33 \%$ of IGF-I deficient patients. Our group's studies have been focusing on them ever since.

In an effort to obtain normative data to establish appropriate cutoff levels for $\mathrm{GH}$ stimulation tests, our group studied the estrogen priming effect on $2 \mathrm{GH}$ provocative tests, sequential arginine and clonidine stimulation [6]. We enrolled 15 GH-deficient patients and 44 ISS children. By estradiol priming, we were able to determine that a GH cutoff level of $9 \mathrm{ng} / \mathrm{ml}$ had $98 \%$ specificity and $100 \%$ sensitivity.

We then were able to establish IGF-I and IGFBP-3 diagnostic efficiencies for $\mathrm{GH}$ deficit using both cohorts of patients. IGF-I had good sensitivity (93\%) but low specific-

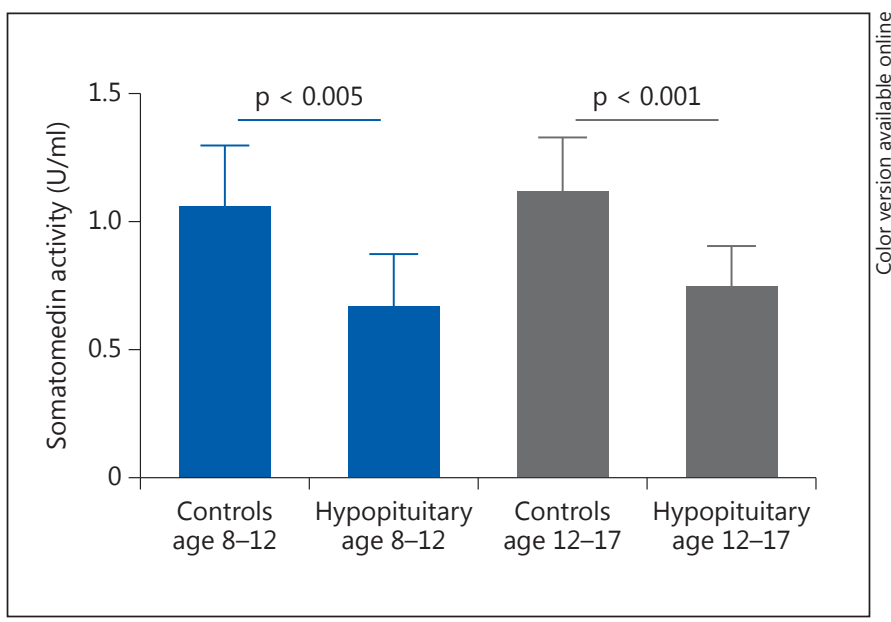

Fig. 3. Somatomedin activity in hypopituitary patients. Controls age 8-12 years $n=15$, controls age $12-17$ years $n=10$, hypox age $8-12$ years $n=7$, hypox age $12-17$ years $n=13$. Bars = means; whiskers $=1 \mathrm{SD}$. Four hypox patients presented somatomedin activity within normal limits. ity (68\%). Its diagnostic efficiency was near 75\%. IGFBP-3 proved better at diagnosing GH deficiency; it had $87 \%$ sensitivity and 93\% specificity, with a diagnostic efficiency of 91\%. Although IGF-I levels are not appropriate for diagnosing GH deficiency, they are useful for identifying IGF anomalies in $\mathrm{GH}$-sufficient but growth-retarded patients. Serum IGF-I levels are also useful to monitor GH treatments to check for compliance and to avoid supranormal values. They are also useful to test for GH insensitivity by the administration of GH for a short period of time.

Regarding ISS patients with low IGF-I levels, where does the problem occur? There might be many possible locations along the intracellular chain of transmission of the GH signal, the first of which is the binding of GH to the GH receptor dimer. This produces conformational changes in the dimer leading to the receptor activation. This in turn produces activation of 4 pathways. One is inhibitory, stimulating the suppressors of cytokine signaling. A second pathway, shared with cytokines, involves the signal transducers and activators of transcription, the STATs $1,3,5 \mathrm{a}$, and $5 \mathrm{~b}$. STAT5b is now recognized as the crucial signaling intermediate for GH-regulated growth; acting in the nucleus, it stimulates transcription of IGF-I, IGFBP-3, and ALS. A third pathway stimulates proliferation involving the mitogen-activated protein kinase and the extracellular signal related kinases 1 and 2. A fourth pathway related to metabolism involves the phosphatidyl inositol 3 kinase. There is cross talk among different pathways, so alterations in one may affect another (Fig. 1).

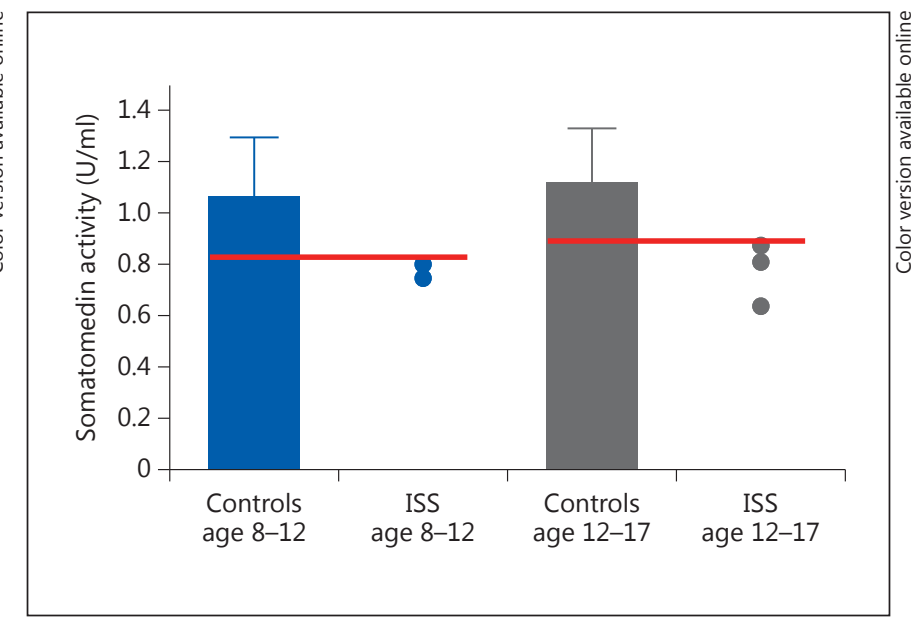

Fig. 4. Somatomedin activity in ISS patients. Age and number of controls same as in Fig. 3. Bars = means; whiskers =1 SD. The horizontal line marks mean $-2 \mathrm{SD}$. 
The first mutation described within the chain of transmission of the $\mathrm{GH}$ signal involved the $\mathrm{GH}$ receptor. Back in 1966, Laron et al. [7] first described what later became known as the Laron syndrome. The authors suggested two possible mechanisms for the patients' short stature: either an abnormal structure of $\mathrm{GH}$ or resistance to a $\mathrm{GH}$ of normal structure. It is remarkable that 49 years later, Zvi Laron just reported "Fifty Seven Years of Follow Up of the Israeli Cohort of Laron Syndrome Patients - From Discovery to Treatment" [8]. The following are some highlights of his work. In 1984, his group reported on the specific binding of labeled $\mathrm{GH}$ and labeled insulin to liver microsomes from 2 patients with Laron syndrome and from a healthy control subject [9]. They showed that specific binding of labeled GH was greatly reduced in the patients when compared with the control group. In contrast, labeled insulin binding was not reduced in the Laron syndrome patients. The results pointed to functional anomalies in the GHR.

In 1989, Amselem et al. [10] reported a paper showing genomic blots hybridized with GHR-exon-specific probes. Blots containing DNA from 2 normal individuals and 2 Laron syndrome patients were hybridized with the exon-specific probes. DNA from the 2 patients failed to hybridize with the probes corresponding to exons 3, 5, and 6. Clearly, genetic mutations in the GHR gene were found. Since then, around 300 cases have been reported, a majority of them carrying point mutations [11, 12]. When the IGF-I SDS values found in patients with Laron syndrome were divided according to the type of mutation present, levels varied widely within each group, but it was clear that pseudoexon and dominant negative mutations had values closer to the normal range, some of them even within normal limits [11].

The response to IGF-I treatment of complete GH resistant patients, the majority Laron syndrome, has been reported [13]. From 21 patients enrolled, only 2 boys and 1 girl reached adult height within normal limits. With only 2 exceptions of very poor responders, the rest of the treated patients reached adult height over the mean of the untreated population, but only 2 boys and 1 girl were over 2 SD above the mean of the untreated cohort, but below the lower limit of normal height.

\section{The Present}

In 1996 Woods et al. [14] opened what we deem is the present stage of the relations between IGFs and growth retardation, describing the first patient with a homozy- gous partial deletion (lack of exons 4 and 5) of the IGF-I gene. The patient presented severe prenatal and postnatal growth failure, sensorineural deafness, and mental retardation. His adult height was around $120 \mathrm{~cm}$, and he was unresponsive to chronic GH treatment. He also presented undetectable IGF-I levels with normal IGFBP-3. Serum IGF-I remained undetectable after 5 days of GH treatment, while his normal IGFBP-3 levels did not change. Serum IGF-II and GHBP were normal. PCR analysis of exons 3, 4, 5, and 6 of the IGF-I gene showed absence of exons 4 and 5 .

In 2003, Abuzzahab et al. [15] made the first report of patients with IGF-I receptor mutations. In subjects with IGF-I receptor malfunction, high IGF-I levels were expected. One patient, with poor fetal and postnatal growth, had already reached an adult height of $134 \mathrm{~cm}(-4.8 \mathrm{SD})$. She was born with weight $3.5 \mathrm{SD}$ below the mean, and did not respond to GH treatment. Basal serum IGF-I was normal at age 4.5 but high 4 years later. She showed no dysmorphic features, had a normal puberty, but presented some psychiatric anomalies. She was compound heterozygote for point mutations in exon 2 of the IGF-I receptor gene (Arg108Gln, Lys115Asn). The other patient also had poor fetal and postnatal growth. Birth length was $5.8 \mathrm{SD}$ below the mean for gestational age, and he presented microcephaly, developmental delay and other dysmorphic features. Serum IGF-I concentrations, measured on several occasions, ranged from 1.1 to $2.3 \mathrm{SD}$ above the mean for age, whereas IGFBP-3 concentrations remained within normal limits. He was heterozygous for a non-sense mutation (Arg59stop) in exon 2 of the IGF-I receptor gene.

Studies of the function of the IGF-I receptor in the first patient revealed mean total specific binding of labeled IGF-I to her cultured fibroblasts significantly reduced when compared to 2 different controls. The binding affinity $(\mathrm{Kd})$ of the patient's fibroblasts was one-third that of the controls. Binding capacities were similar between patient and controls. The mutation in the second patient reduced the number of IGF-I receptors on his cultured fibroblasts.

Also in 2003, Kofoed et al. [16] reported the first patient presenting "Growth hormone insensitivity associated with a STAT5b mutation." Poor weight gain and growth failure were noted during the first 3 years of life, and evaluations for failure to thrive and malabsorption revealed no abnormalities. GH response to stimulation was normal. Serum concentrations of IGF-I, IGFBP-3, and ALS were all markedly low, with poor responses to 7 consecutive daily injections of rhGH. At 7 years of age, 
Fig. 5. Ternary complex formation. Results of size exclusion column chromatography. Serum samples from a normal control (A), a patient with a $\mathrm{GH}$ deficiency (B), and a patient with the acid-labile-subunit deficiency (C) were analyzed. The regions corresponding to the ternary complexes are shown in the shaded boxes. Arrows indicate the positions of markers of the molecular weight. In $\mathrm{A}$, serum shows the formation of ternary complexes. In $\mathrm{B}$, the formation of ternary complexes peaks after treatment with recombinant human $\mathrm{GH}$ (rhGH). In C, even after rhGH treatment, there was no increase in the formation of ternary complexes. Reprinted with permission from Domené et al. [17].

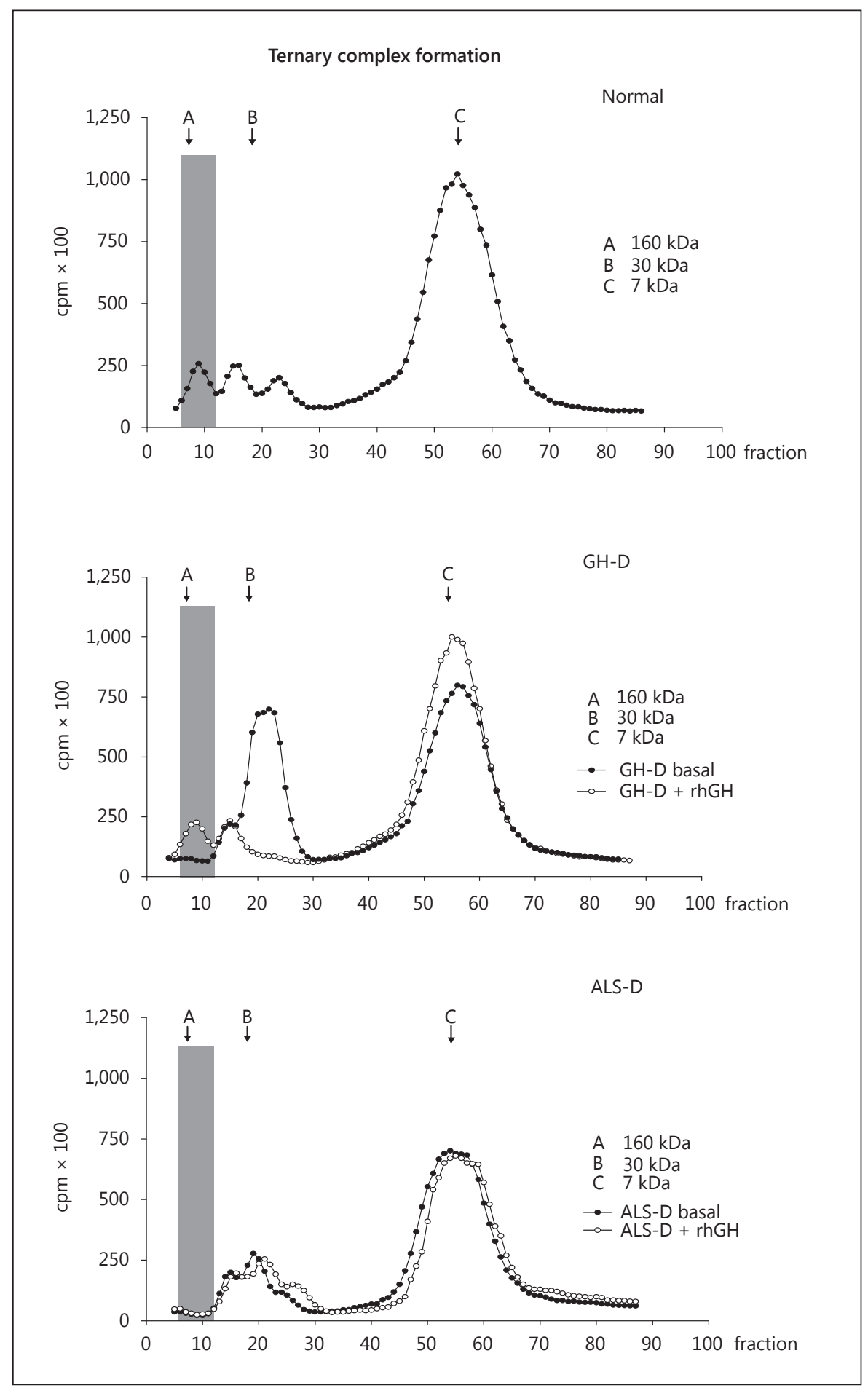

her height and weight were both far below the 5th percentiles. She also had respiratory difficulties, with increased oxygen requirements; a lung biopsy showed lymphoid interstitial pneumonia. She then had multiple episodes of bronchial obstruction, severe hemorrhagic varicella and several episodes of herpes zoster. A 12-month trial of GH therapy resulted in no improvement in growth rate. The patient was homozygous for a single nucleotide change within the SH2 domain of STAT5b. The mutation resulted in an amino acid substitution of proline for alanine at 
position 630 (Ala630Pro). Immunoblots for total STAT$5 \mathrm{a}$ and total STAT5b, corresponding to the patient's fibroblasts, showed presence of STAT5a, but absence of STAT5b. In addition, even after GH stimulation, phospho-STAT5b persisted absent. These results suggested either that the patient lacked STAT5b, or that the epitope recognized by the specific monoclonal antibody was affected by a mutation and raised questions concerning the ability of this protein to be activated. Further studies revealed that the mutant protein could be expressed but could not be phosphorylated, thus losing its activity. Since cytokines share the STATs pathway, the lack of STAT5b activity contributes to explain the immunologic alterations seen in this patient.

In 2004, our group reported the first patient carrying complete ALS deficiency (ALS-D) due to inactivation of the IGFALS gene [17]. The patient presented slightly affected height, pubertal delay, insulin insensitivity, and reduced bone mineral density. Basal IGF-I levels were very low (around -5 SDs) and IGFBP-3 levels were even lower (oscillating between -7.6 and -9.9 SDs). His nocturnal $12-\mathrm{h}$ GH profile showed an increase in GH secretion. His GHBP was normal. Neither growth, nor IGF-I or IGFBP-3 responded to 6 months of rhGH treatment. The pattern of greater reductions in IGFBP-3 than in IGF-I levels was subsequently found characteristic of ALS deficiency. Accordingly, ALS levels were undetectable all along. Sanger sequencing showed a frameshift mutation (p.E35Kfs*87) that causes a premature stop codon. Immunoblots using antibodies against different epitopes of the ALS protein failed to recognize ALS protein.

In the circulation, about $85 \%$ of the IGFs are found forming a $150-\mathrm{kDa}$ ternary complex with ALS and either IGFBP-3 or IGFBP-5. About $15 \%$ of the IGFs are found forming binary complexes with one of the binding proteins, and less than $1 \%$ is found free. Looking to prove absence of ALS in the patient's serum, we performed in vitro ternary complex formation. Figure 5 shows that normal serum forms a ternary complex peak at about 150 $\mathrm{kDa}$, and a binary peak at about $30 \mathrm{kDa}$. Serum from a $\mathrm{GH}$-deficient patient shows a small basal ternary complex peak that increases significantly after GH treatment. Serum from the ALS-D patient showed no ternary complex formation either before or after GH treatment. Since this report, complete ALS deficiency has been identified in at least 36 patients. By the combined use of in silico and functional in vitro studies, we characterized 11 IGFALS gene variants previously described in ALS-D or ISS children as likely pathogenic or benign by bioinformatics tools [18].

\section{The Future}

Two patients symbolized for us the beginning of the future of our knowledge on the relationship between growth retardation and the IGF system (an arbitrary cutoff point), marked by the use of whole exome (and further away by whole genome) sequencing. Mass sequencing portrays a faster pace in the acquisition of knowledge within this field. One patient presented with short stature, recurrent pulmonary diseases, oxygen requirement, chronic diarrhea, severe eczema, low IGF-I, with over 30 hospitalizations. At a first impression, the condition was compatible with a STAT5b mutation. Nevertheless, Sanger sequencing revealed no mutation in the STAT5b gene. The other patient presented short stature, had pulmonary distress, chronic diarrhea and vomiting, abdominal distention, severe eczema, history of colitis, proctitis, a GI tract biopsy with intraepithelial lymphocytosis, and low IGF-I. His clinical characteristics were compatible with an IPEX-like syndrome, but no mutation was found in the FOXP3 gene. Whole exome sequencing identified two different gain of function heterozygous STAT3 variants: a private de novo c.1847_1849delAAG (p.Glu616del) mutation in the $\mathrm{SH} 2$ domain in the first patient, and a missense c.1276T $>C$ (p.Cys426Arg) mutation in the DNA binding domain in the second patient [19].

Mass sequencing also allowed a further understanding of the relationship between the IGF binding proteins and abnormal human growth. There is, for studying the reduced actions of binding proteins, a mouse model available [20]. On the other hand, recent data concerning the pregnancy-associated plasma protein A2 (PAPP-A2) mutations in children [21] increased our knowledge on the increased action of IGFBP-3 and IGFBP-5. PAPP-A2 is a metalloproteinase specific for IGFBP-3 and IGFBP-5. It is present in the intravascular compartment and also at the tissue level.

The mouse model for studying the reduced action of binding proteins involves a transgenic mouse (named KID) for an IGF-I analog with equal capacity for IGF-I receptor stimulation but with reduced affinity for the IGF-binding proteins. The wild-type mice had more than double the amount of circulating IGF than KID mice, although body weight and length for KID mice were significantly increased when compared to wild type. This increased growth is not harmonic, not proportionate, i.e. expressing organ weight as percent of body weight, KID mice showed reductions in some organs: liver (14\%), gonadal fat $(50 \%)$, quadriceps muscle $(46 \%)$, mammary gland $(39 \%)$, and increments in others: pancreas (55\%), kidney (24\%), and uterus and ovaries (83\%) [20]. 


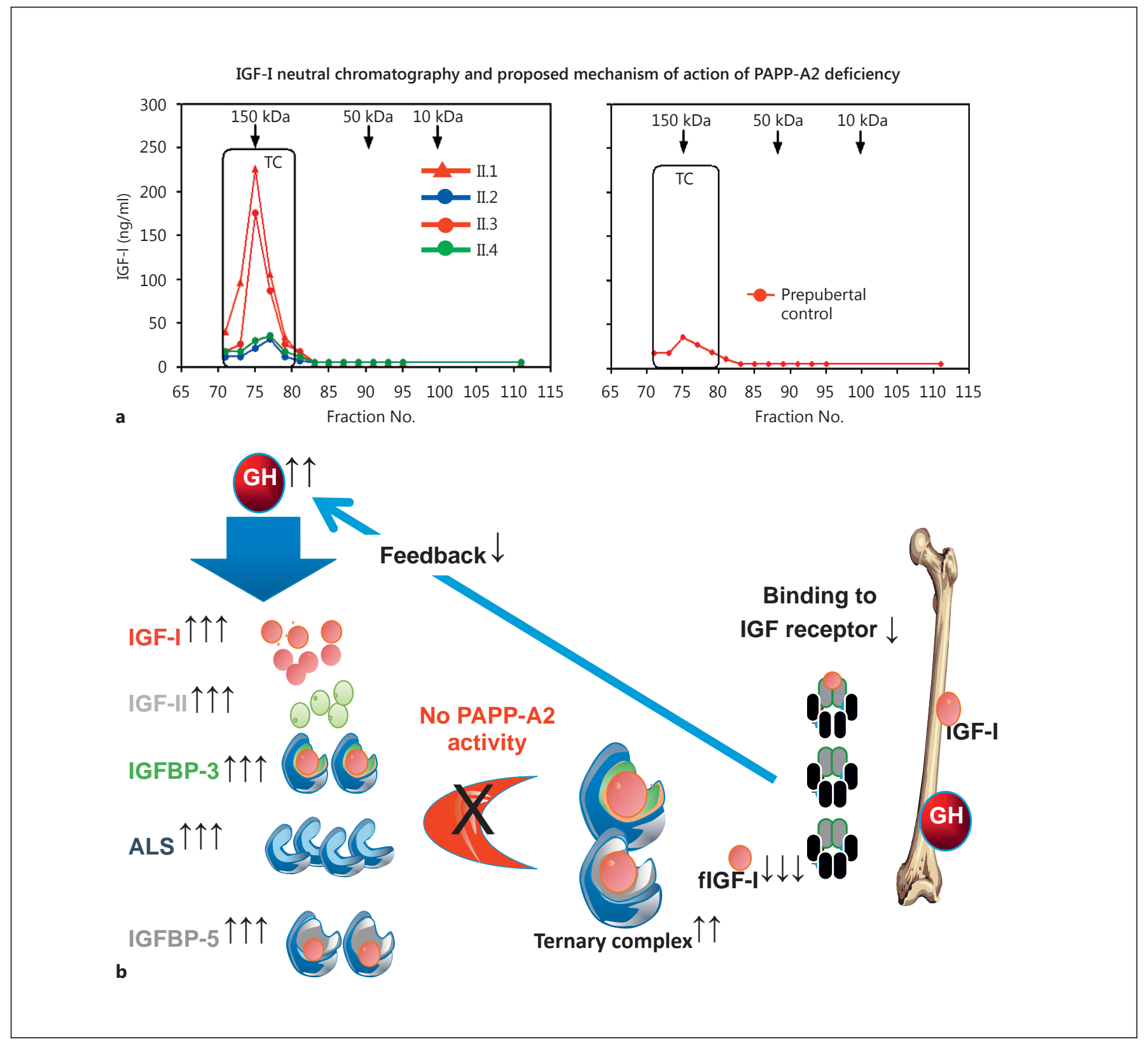

Fig. 6. a Concentrations of endogenous IGF-I in the different fractions obtained by neutral size exclusion chromatography on a Superdex 200 column. Serum samples from the 4 siblings of family 1 were analyzed and compared with a prepubertal control (all siblings were prepubertal). The amount of IGF-I detected in the ternary complex (TC) was markedly greater in the homozygous affected subjects (II.1 and II.3) compared to the unaffected siblings (II.2 and II.4) and the prepubertal control. No IGF-I was detected in the fractions corresponding to the binary complex or free IGF-I in any of the subjects, probably because the amount of IGF-I in the BC or free was below the level of detection of the IGF-I assay. $\mathbf{b}$ Cartoon of the hypothesized mechanism underlying growth failure due to lack of PAPP-A2. (1) There is decreased proteolysis of IGFBP-3 and IGFBP-5 due to the lack of PAPP-A2 activity. (2) This causes an increase in the formation of ternary complexes. (3) This results in reduced concentrations of free IGF-I. (4) Consequently, this decreases the negative feedback effect of IGF-I on GH production, increasing circulating GH. (5) This elevates serum concentrations of IGF-I, IGFBP-3 and ALS, further increasing ternary complex formation. Reprinted with permission from Dauber et al. [21]. 
Surprisingly, the only known gene mutations causing excess binding protein action in humans do not produce overexpression of one or more binding proteins, but a reduction in proteolysis of IGFBP-3 and IGFBP-5. These patients carry mutations in PAPP-A2. The report involves subjects from two families, one of Spanish ancestry (family 1), the other of Palestinian ancestry (family 2). Family 1 patients had height within normal limits, but well below their target height, the others had height clearly below the third percentile. All these patients show long fingers and toes and long and thin fibulae, tibiae and femurs. In family 1 , the affected children have high serum IGF-I, IGF-II, IGFBP-3, IGFBP-5, ALS, and insulin. In family 2 , the 3 siblings only show high IGF-I, IGFBP-3, and insulin [21].

By whole exome sequencing, the affected children from family 1 were found homozygous for the PAPP-A2 frameshift mutation p.D643fs $25^{*}$, which causes a premature stop codon; the affected children from family 2 were found homozygous for a different novel missense variant, p.Ala1033Val.

To study the functional alterations produced by these mutations, cells were transfected with the wild-type PAPP-A2 and with the two mutations. As expected, wildtype PAPP-A2 proteolyzes IGFBP-3 and IGFBP-5, but not IGFBP-4. The conditioned media from cells transfected with the mutations did not proteolyze IGFBP-3, 5, or 4. Western blots of serum from patients carrying the p.D643fs25* frame shift mutation lacked the protein, while serum from patients with the p.Ala1033Val mutation, under reduced conditions, showed 2 fragments of the protein. Apparently, this protein could be secreted, but was inactive. As PAPP-A2 cleaves IGFBP-3 and 5, thereby releasing IGF-I from the ternary complex, the authors hypothesized that lack of PAPP-A2 activity would decrease free IGF-I (fIGF-I) in the mutated subjects, even in the presence of elevated total IGF-I concentrations in the ternary complexes (Fig. 6).

Indeed, fIGF-I concentrations were low in 4 of 5 patients, suggesting that they have a functional defect in the ability to free IGF-I from its binding proteins. To further prove the hypothesis, IGF bioactivity (the potential of the patients' serum to stimulate the IGF-I receptor in vitro) was studied and found to be lower in the prepubertal patients compared to unaffected prepubertal subjects, with the percentage of bioactive IGF (bioactive IGF/total IGFI) reduced in all affected patients. The findings in these patients point to PAPP-A2 as a key regulator of IGF-I bioavailability and show that altered IGFBP function can modify human growth.
Finally, also through whole exome sequencing, a recent report appeared concerning a "Paternally Inherited IGF-II Mutation and Growth Restriction" [22]. The mutation, p.Ser64Ter, was a heterozygous non-sense substitution in exon 3 of the IGF-II gene, which was predicted to result in a premature stop codon. An important point is that the liver is the only organ with biallelic expression of the IGF-II gene. In the rest of the organism, the IGF-II gene is maternally imprinted. As the liver is an important source of circulating IGF-II, and since these patients have one mutated and one wild-type allele, some IGF-II could be found in plasma. The characteristics of these patients include: birth length at least $4 \mathrm{SD}$ below the mean, relative macrocephaly at birth; as adults, 2 out of 3 conserved the relative macrocephaly; before GH treatment, IGF-II levels were below the fifth percentile in 2 out of 3 , the $3 \mathrm{rd}$ one was just at the fifth percentile; after GH treatment, the low IGF-II levels increased to the normal range.

It is interesting to compare the characteristics of those patients carrying an IGF-I mutation with those carrying an IGF-II mutation. First, there are differences in the mode of inheritance, the former is autosomal recessive, the latter by genomic imprinting. While microcephaly is present in the patients with IGF-I mutations, relative macrocephaly is seen in the patients with IGF-II mutations, where dysmorphisms associated with the Silver Russell Syndrome could also be present. Finally, patients with IGF-I mutations did not respond to GH treatment, while some patients with IGF-II mutations showed satisfactory responses.

Since several hundred genes are involved in the growth process [23], near-future challenges might include:

- Difficulties to discern, among the variants found by whole exome sequencing, the one responsible for the phenotype

- The lack of analysis of a significant part of the exome; currently, an important part escapes analysis for different technical reasons [24-28]

- The possible association among several variants to contribute to the phenotype

- The epigenetic origin of the phenotype

In the not so distant future, younger generations (including present residents, fellows, PhD candidates) will have the chance to see how right or wrong we were, and to increase our knowledge concerning growth defects. In addition, these new generations will tell if the technical advances now in progress give the expected results, if the pace of improvement is slow or fast, and if new and unexpected methods appear. Let us wish them good results, and the chance to make wonderful discoveries to improve our children's health. 


\section{Acknowledgements}

The author is grateful to Sabina Domene, $\mathrm{PhD}$, for help with the revision of the manuscript.

\section{Disclosure Statement}

The author has no financial conflict of interest related to this work.

\section{References}

-1 Casanova JL, Holland SM, Notarangelo LD: Inborn errors of human JAKs and STATs. Immunity 2012;36:515-528.

$>2$ Salmon W, Daughaday W: A hormonally controlled serum factor which stimulates sulfate incorporation by cartilage in vitro. J Lab Clin Med 1957;49:825-836.

3 Le Roith D, Bondy C, Yakar S, Liu J, Butler A: The somatomedin hypothesis: 2001. Endocr Rev 2001;22:53-74.

4 Kaplan S, Cohen P: The somatomedin hypothesis 2007: 50 years later. J Clin Endocrinol Metab 2007;92:4529-4535.

5 Jasper H, Martinez A, Heinrich J: Somatomedin activity in patients with growth retardation due to hypopituitarism or familial-constitutional growth delay; in Spencer EM (ed): Insulin-like Growth Factors/Somatomedins. New York, Walter de Gruyter, USA 1983, pp 259-262.

6 Martinez A, Domene H, Ropelato G, Jasper H, Pennisi P, Escobar M, Heinrich J: Estrogen priming effect on growth hormone $(\mathrm{GH})$ provocative test: a useful tool for the diagnosis of GH deficiency. J Clin Endocrinol Metab 2000; 85:4168-4172.

7 Laron Z, Pertzelan A, Mannheimer S: Genetic pituitary dwarfism with high serum concentration of growth hormone. A new inborn error of metabolism. Israel J Med Sci 1966;2: $152-155$.

$>8$ Laron Z, Kauli R: Fifty seven years of follow up of the Israeli cohort of Laron syndrome patients - from discovery to treatment. Growth Horm IGF Res DOI: 10.1Z016/j.ghir.2015. 08.004 .

$\checkmark 9$ Eshet R, Laron Z, Pertzelan A, Arnon R, Dintzman M: Defects of human growth hormone receptors in the liver of two patients with Laron-type dwarfism. Israel J Med Sci 1984;20:8-11.

$>10$ Amselem S, Duquesnoy P, Attree O, Novelli G, Bousnina S, Postel Vinay M, Goossens M: Laron dwarfism and mutations of the growth hormone receptor gene. N Engl J Med 1989; 321:989-995.

$>11$ David A, Hwa V, Metherell L, Netchine I, Camacho-Hubner C, Clark A, Rosenfeld R, Savage M: Evidence for a continuum of genetic, phenotypic, and biochemical abnormalities in children with growth hormone insensitivity. Endocr Rev 2011;32:472-497.
2 Mullis PE: Genetics of GHRH, GHRH-receptor, $\mathrm{GH}$ and $\mathrm{GH}$-receptor: its impact on pharmacogenetics. Best Pract Res Clin Endocrinol Metab 2011;25:25-41.

13 Backeljauw P, Kuntze J, Frane J, Calikoglu A, Chernausek S: Adult and near-adult height in patients with severe insulin-like growth factor-I deficiency after long-term therapy with recombinant human insulin-like growth factor-I. Horm Res Paediatr 2013;80:47-56.

14 Woods K, Camacho-Hübner C, Savage M, Clark A: Intrauterine growth retardation and postnatal growth failure associated with deletion of the insulin-like growth factor I gene. N Engl J Med 1996;335:1363-1367.

15 Abuzzahab M, Schneider A, Goddard A, Grigorescu F, Lautier C, Keller E, Kiess W, Klammt J, Kratzsch J, Osgood D, Pfäffle R, Raile K, Seidel B, Smith R, Chernausek S: IGF-I receptor mutations resulting in intrauterine and postnatal growth retardation. N Engl J Med 2003;349:2211-2222.

16 Kofoed E, Hwa V, Little B, Woods K, Buckway C, Tsubaki J, Pratt K, Bezrodnik L, Jasper H, Tepper A, Heinrich J, Rosenfeld R: Growth hormone insensitivity associated with a STAT5b mutation. N Engl J Med 2003;349: 1139-1147.

17 Domené H, Bengolea S, Martinez A, Ropelato M, Pennisi P, Scaglia P, Heinrich J, Jasper H: Deficiency of the circulating insulin-like growth factor system associated with inactivation of the acid-labile subunit gene. $\mathrm{N}$ Engl J Med 2004;350:570-577.

18 Martucci L, Gutiérrez M, Karabatas L, Scaglia $\mathrm{P}$, Rey R, Domené H, Jasper H, Domené $\mathrm{S}$ : Assessment of pathogenicity of natural IGFALS gene variants by in silico bioinfor matics tools and in vitro functional studies. Mol Cell Endocrinol 2016;429:19-28.

19 Scaglia P, Keselman A, Gutiérrez M, Domené S, Blanco M, Sanguinetti N, Bezrodnik L, Di Giovanni D, Caldirola M, Martucci L, Karabatas L, Hawa Jones N, Hwa V, Revale S, Vázquez M, Jasper H, Kumar A, Domené H: Severe IGF-I deficiency and multi organ auto immune disease associated with novel germ line STAT3 mutations (abstract). XXV Annual Meeting of the Latin American Pediatric Endocrinology Society (SLEP), November 3-6, 2015, Puerto Varas, Chile. Horm Res Paediatr 2015;84(suppl 2):38.
20 Elis S, Wu Y, Courtland H, Cannata D, Sun $\mathrm{H}$ Beth-On M, Liu C, Jasper H, Domene H, Karabatas L, Guida C, Basta-Pljakic J, Cardoso L, Rosen C, Frystyk J, Yakar S: Unbound/ bioavailable IGF-1 enhances somatic growth. Dis Model Mech 2011;4:649-658.

21 Dauber A, Muñoz-Calvo M, Barrios V, Domené H, Kloverpris S, Serra-Juhé C, Desikan V, Pozo J, Muzumdar R, Martos-Moreno G, Hawkins F, Jasper H, Conover C, Frystyk J, Yakar S, Hwa V, Chowen J, Oxvig C, Rosenfeld R, Pérez-Jurado L, Argente J: Mutations in pregnancy-associated plasma protein A2 cause short stature due to low IGF-I availability. EMBO Mol Med 2016;8:363-374.

22 Begemann M, Zirn B, Santen G, Wirthgen E, Soellner L, Büttel H, Schweizer R, van Workum W, Binder G, Eggermann T: Paternally inherited IGF2 mutation and growth restriction. N Engl J Med 2015;373:349-356.

23 Wood AR, et al: Defining the role of common variation in the genomic and biological architecture of adult human height. Nat Genet 2014;46:1173-1186.

24 Damiati E, Borsani G, Giacopuzzi E: Amplicon-based semiconductor sequencing of human exomes: performance evaluation and optimization strategies. Hum Genet 2016;135: 499-511.

25 Shigemizu D, Momozawa Y, Abe T, Morizono T, Boroevich KA, Takata S, Ashikawa K, Kubo M, Tsunoda T: Performance comparison of four commercial human whole-exome capture platforms. Sci Rep 2015;5:12742.

26 Goodarzi MO: Genetics of common endocrine disease: the present and the future. J Clin Endocrinol Metab 2016;101:787-794.

27 Guo MH, Shen Y, Walvoord EC, Miller TC, Moon JE, Hirschhorn JN, Dauber A: Whole exome sequencing to identify genetic causes of short stature. Horm Res Paediatr 2014;82: 44-52.

28 Altmüller J, Motameny S, Becker C, Thiele H, Chatterjee S, Wollnik B, Nürnberg P: A systematic comparison of two new releases of exome sequencing products: the aim of use determines the choice of product. J Biol Chem 2016;397:791-801 